\title{
松江藩における御大工の位置付けとその推移
}

（松江藩御作事所と御大工の作事に関する研究 その 2)

\section{ON THE RANKS AND GENEALOGY OF THE MATSUEHAN-ODAIKU}

A study on the "Matsuehan-Osakujidokoro" and the works of "Odaiku" Part 2

\author{
和田 嘉 宥* \\ Yoshihiro WADA
}

\begin{abstract}
We have a source book "Osakujidokoro-Oyakuninchou" on the personnel changes in the officials or the carpenters who worked for Osakujidokoro.

In this study, first of all, the writer tells the ranks of the Odaiku in the Osakujidokoro according to the "Osakujidokoro-Oyakuninchou" and the "Kyuhanjiseki-Sitakosirae".

Next, the writer confirms the ranks of the Odaiku in the Edo period.

Lastly; the writer tells the genealogy of the Matsuehan-Odaiku.
\end{abstract}
Keyword: Matsuehan, Osakujidokoro(the office of constructive), Odaiku(master carpenter), ranks, genealogy, changes 松江藩、御作事所、御大工、位置付け、系譜、推移

\section{1.はじめに}

松江藩には作事を扱う役所として御作事所があり、御作事所に 勤める大工瞕や役人の変動を記した史料に『御作事所御役人艮』1 （以下、『帳』と記す）が現存する。前稿 2 では『帳』の記載内容を 検討し、この史料が近世における御大工の系譜とその推移を伝え る貴重な史料であることを明らかにし、続いて『艮』を基礎史料 として御作事所の人員構成とその変䢙を辿り、御作事所の員数と 活動状況との対応を検証した。また、御作事所が関与した作事に ついて検討を加え、松江藩御作事所の作事が、城内の維持管理の みに留まらず、藩内の寺社建築の修造や建造、橋の掛け替え、さ らには幕府の普請手伝いと多岐に渡っていることを確認した。

本研究は、地方における作事組織の実態と組織形態を具体的に 検証し、御大工の活動と推移を明らがにできところに特色があ ると考えているが、本稿では、まず最初に松江藩御作事所におけ る大工職の位置付けを明らかにし、続いて、御作事所の役職と格 式との関係を確認する。さらに、松江藩御作事所において中心的 な存在となっていた御大工について、その系譜を幾つか追跡する ことによって、御大工の推移の一端を明らかにし、松江藩御大工 の特色を考察したい。

\section{2. 松江落御作事所の特色 ${ }^{3}$}

松江藩に関する記録史料として「雲州松平家文書」があり、そ の一つ『旧藩事蹟調查下按』 4 (以下『下按』之記す) の内、『五 之拾壹』に御作事所に関する記述があるが、その内容は次の通り である。
十一御作事奉行 是レ八定員三名 内志名八江戸勤番ありし 外二添奉行先ツ八二名 内一人八多く御大工ト申シテ元親代ヨリ 其職に従事 御大工頭卜なり御徒格二も進ミ常二何も心得居て后 新番士二取立られ調方卜力押合卜力 それに此御作事所二八破損 方或八修理方の名アリテ 是木作事奉行ニテ兼勤之為メニ八間二 八破損方添奉行又八修理方添奉行二テ 遂二御䜺代士御留守居番 組へ組入 全ク添奉行と又繰上けの末 此役組外二進ミ本奉行二 被仰付モ，是迄続々ありし

元来御作事所卜申シ 新規御国にての御普請ト云へ八 御九代 齊貫公の御隐居後の御住居 元御花畑内二御新筑二なりし 観山 御殿卜力其後新御殿ト申シテ 元御鹰部屋跡へ若殿様御殿力建築 セラれしトカ 其前文武入交セの槢古所則修道館卜力習兵所习開 カレ 幾分建物力出来タト申又 凡ソ五六十年以来の御普請ケ所 記セ八如斯其他修繥 官の手懸り場所トナレ八 諸役所旧の 諸稭古場 従来大橋の架橋、橋々修繥卜テ 江戸御屋教八別段勤 番もあり 京大坂の屋教二セヨ 御普請トナレハ一切此御作事所 の掌る所

尚 破損方寺社修理方卜力其区別あり 尤杵築御造営卜テ藩 の関係なきにあらず ソコデ役所に二八 計吏八普通内改以下元 メ下役人八申迄もなく 外二御大工御左官又城普請の者卜力 皆 作事支配之者も有りて夫々従事 前記御大工頭となりての添奉行 又ハ本奉行二進ムモノ八普通の奉行卜違ひ其道に委しけれれ 職 人二も手抜力出来め

以下御大工木二八時宜二よつて八 自身二鋸切り鉄棺を取り てヤリて見七る そこ八大に用ゆる所 間に八夫れ者其もの居て 取引する故二八 職人も頭あからさる事も可有之，併此儀爱二 記置クヘシ 
『下按』は松江藩軍用方書役重村俊介が幕末における松江藩の 様子を多岐に渡って記録したものだが、江戸時代末期における松 江藩御作事所の特色と御大工の働きがよく分かる。以下、『下按』 記載内容の要点を示す。

・作事奉行の定員は 3 名で、内 1 人は江戸勤番となる。

・添奉行は 2 名で、内 1 人は御大工から取立られる。御大工は 御大工頭となり御徒になり、さらに添奉行になり新番士となる。

・添奉行から本奉行になり組士となり、さらに役組外になる者 も少なくない。

・御作事所の仕事は、城内の建物（藩主隱居後の住居、若殿の 住居）、倣外に設ける新規の藩の建物（修道館）などの普請が主 で、その他は、役所、大橋などの橋の修繥があった。

・江戸屋敷には江戸勤番が置かれた。

・破損方、寺社修理方も置かれた。

・杵筑大社造営も御作事所にとって重要な任務だった。

・役所には、事務系として計吏を扱う内改、元メ、下役人等が、 技術系として作事支配の御大工、御左官、城普請等が置かれた。

・御大工は、鋸などの大工道具の扱いは優れており、その道に よく通じており、職人達も御大工には一目おき、仕事にも手抜き が出来かねた。

\section{3. 御作事所の檴成と御大工の位固付け}

さて『艮』をめくると、天明 5 年(1785)までは御大工を中心に 召抱（登用）をはじめ移動のあった人名とその役職等しか記載さ れていない。これに対して天明 6 年(1786)以降の『帳』は、御作 事所に勤める作事奉行・御役人・御大工・城普請等の人名が全て 記載されており、その年の御作事所の全容を知ることができる。

天明 6 年の『帳』によって松江藩御作事所の陣容をまとめると、 表一 $1^{6}$ となる。

ここでは、天明 6 年の『帳』によって御作事所の構成要員につ いて確認し、役職と格式の相互関係についても考察を加える。

当時の御作事所の員数は凡そ 70 名 7 である。作事奉行が御作事 所を統括し添奉行 2 名がそれを補佐している。その下に調役・内 改・横目・元み・役人・御大工頭・御大工・御大工並・御左官等 が配㯰されている。大工職の勤めは普請所が主体であるが、他に 破損方、誂物小繥御急手方外方があり、江戸勤番もあった。城普 請が 16 名となっているが、これら城普請は城普請小頭の指揮下 にあって、その役目は「道具方、御破損方、御急手誂物外小繥方、 左官壁土趣向、御作事所破損方御普請所損見迴」等であったこと が分かるが、多くは御大工、御左官等の補佐役だったと見える。 江戸勤番（詰）には、添奉行 1 名、御大工頭 1 名、御大工 1 名、 城普請 1 名が配置されていたことも分かるが、御作事所にとって 江戸勤番（詰）は重要な勤めだったと思われる。

松江藩でも格式は表-2のように士分と徒以下（卒分）に二分 されている。御作事所では、奉行・添奉行の格式は役組外、新番 士と並士（士分）で、御大工頭はじめ大工職等の格式は卒分つま り徒以下であることが分かる。

なお松江藩の場合、大工職から添奉行、さらに奉行になる者が いるが、天明 6 年(1786)の『艮』に記されている添奉行闾田彦吉、 内藤領左衛門の二人は何れも御大工からの登用である。
斎田彦吉は、延享 4 年(1741)見習として御作事所に入り、宝暦 元年(1751)に親彦四郎の跡を継ぎ御大工になる。その力量が認め られたのだろう、翌 2 年には御大工頭となり、安氷 2 年(1773)に 添奉行に、天明 9 年(1789)には作事奉行になっている。

また、内藤領左衛門は、寛保 2 年(1741)に御大工並となり、宝 暦 3 年(1751)に御大工になる。同 11 年(1761)には御大工頭とな り、天明 3 年(1783)に添奉行になっている。

表- 1 松江藩御作事所の陣容一覧（天明 6 年）

\begin{tabular}{|c|c|c|c|}
\hline 役 職 & 数 & 格 式 & 備 \\
\hline 奉行 & 1 & 役組外 & 破損方、寺社修理方兼 \\
\hline 添奉行 & 2 & 新番組士 & 内江戸勤番 1 \\
\hline 調役 & 1 & 新番組士 & \\
\hline 内改 & 1 & 御目見格 & \\
\hline 横目 & 6 & $\begin{array}{l}\text { 御徒 } 1 \text { 、御徒並 } 1 \\
\text { 小算用 } 1 \text { 、萬役人 } 3\end{array}$ & \\
\hline 元 & 3 & 萬役人 3 & 内江戸勤番 1 \\
\hline 添元 $\infty^{\infty}$ & 1 & 先手組 & \\
\hline 御大工頭 & 5 & 御徒 1 、御徒並 4 & 内江戸勤番 1 \\
\hline 御大工 & 7 & 御目見格 & $\begin{array}{l}\text { 普請所勤 4、破損方勤 1、 } \\
\text { 江戸勤番 1、 そ他 1 }\end{array}$ \\
\hline 御大工並 & 3 & 譜代格 & 普請所勤 \\
\hline 御大工見習 & 3 & 無給 & 御大工頭倅 1 、御大工卒 2 \\
\hline 御左官 & 2 & 御大工と同格 & \\
\hline 御役人 & 2 & 御目見格 1 、譜代格 1 & \\
\hline 城普請小頭 & 1 & & \\
\hline 城普請 & 16 & 取立物 & 内江戸詰 1 \\
\hline 古物方 & 5 & \begin{tabular}{|l} 
萬役人 1 、先手組 1 、浮組 1 、 \\
同心組 1 、城普請組 1
\end{tabular} & \\
\hline 誂物小繥御 & 3 & 浮組 1 、先手組 1 、 & \\
\hline 急手外方 & & 城普請組 1 & \\
\hline 小夫 & 6 & 御小人 & \\
\hline 鍛冶 & 1 & & \\
\hline 橋大工棟梁 & 1 & & \\
\hline
\end{tabular}

表-2 松江藩の格式 ${ }^{8}$

\begin{tabular}{|c|c|}
\hline 士分の格式 & 卒分（徒以下）の格式 \\
\hline $\begin{array}{ll}\text { 一家老 } \\
\text { 上 } \\
\text { 家老並 } \\
\text { 士 } \\
\text { 中老 } \\
\text { 家老嫡子 }\end{array}$ & $\begin{array}{l}\text { 徒 } \\
\text { 徒並 } \\
\text { 御目見 } \\
\text { 小算用 }\end{array}$ \\
\hline $\begin{array}{ll}\text { 一番頭 } \\
& \text { 目付 } \cdot \text { 歩行頭 } \\
\text { 並 } & \text { 使番 } \\
& \text { 側役 } \\
\pm & \text { 組外 } \\
& \text { 役組外 } \\
& \text { 鹰従番組士 } \\
& \text { 大番組士 } \\
& \text { 留守居番組士 } \\
& \text { 新番組士 }\end{array}$ & $\begin{array}{l}\text { 諧代組足軽 } \\
\text { 浮組足軽 } \\
\text { 犬毫、先手組、同心組他 } \\
\text { 新組足軽 } \\
\text { 杖付、城普請、水主他 } \\
\text { 取立物 } \\
\text { 中間以下 } \\
\text { 中間、百人者、小人他 }\end{array}$ \\
\hline
\end{tabular}

\section{4.御大工の推移}

御大工の推移を辿ると、技倆のある者は、前述した斉田彦吉、 内藤領左衛門のように、御大工並から御大工へ、さらには添奉行、 
表-3 寛延 15 年召抱御大工の系譜

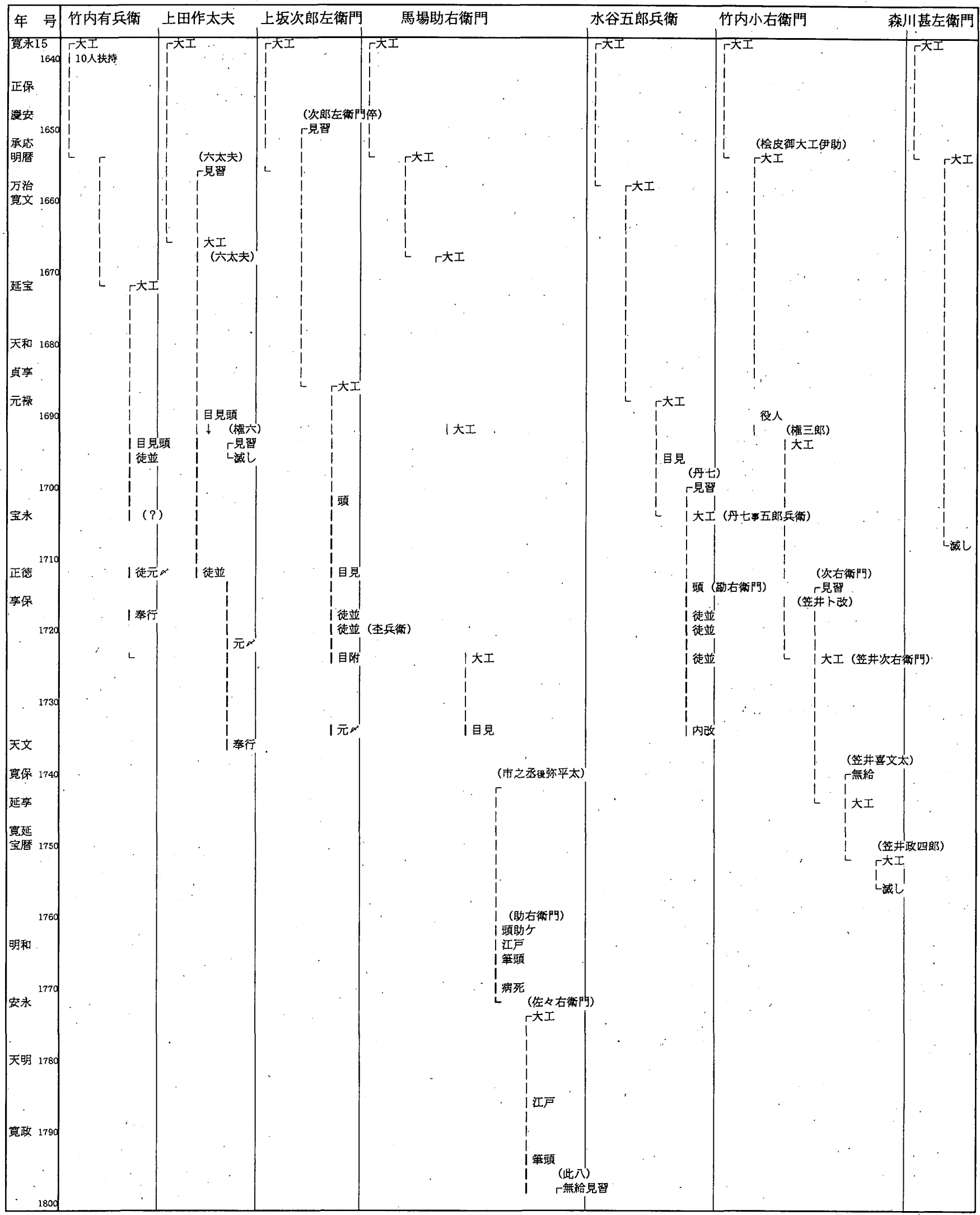

そして本奉行へと昇進しているのが分かる。ここでは、御大工の 系譜を辿り、御大工の家系がどのように推移してるか確認し、松 江藩における御大工の推移の特色を明らかにしたい。使用した史
料には『御作事所御役人埐』以外に『列士録』がある。

1）寛氷 15 年召抱御大工とその系譜 ${ }^{10}$

寛永 15 年、松平直政入部に伴い来松した御大工は 7 人いる。 
まず、これら御大工 7 人とその子孫の推移を辿ってみたい。以下、 御大エ 7 人とその子孫の動向の概要を記す。表- 3 はその推移を まとめたものである。

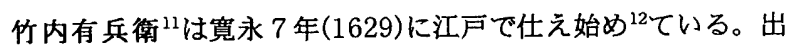
雲入国前、紀州家に召抱えられる約束もあったが、それを反古に し、寛承 15 年(1638)加ら松江藩御大工頭となる。慶安 2 年に江 戸で「西御丸御普請手伝」 ${ }^{13}$ を勤める。倅有兵衛は承応 3 年(1654) に父の跡を継ぎ御大工頭となる。明暦大火後には江戸屋敷の「御 普請御用」を勤める。その倅有兵衛は寛文 11 年(1671)に御大工 頭を継ぐ。元禄 10 年(1697)に江户城で「田安御殿普請手伝」を 勤める。佐太神社貞享度造替では配置替え等注目すべき造営に関 わるが、これを正神主勝部吉成は「竹内氏世稀ナリシ」 ${ }^{14}$ と評価 している。享保 3 年(1718)には作事奉行を勤め役組外になる。奉 行は享保 18 年(1733)に辞退するが、出雲大社延享度造替にも関 わり「年来切者二有之者」として裹美を賜る。『竹内右兵衛書付』 15を記したのもこの人物とされている。以降の代は士格で留守居 番組、大番組等にあり、御作事所からは離れている。

上田作太夫 ${ }^{16}$ は元和年中に足軽並として仕え始めるが、寛永 年中、松本で御大工となる。倅六太夫は明暦 2 年(1656)から御作 事所に勤め始め、寛文 6 年(1666)に父の跡を秤ぎ御大工となる。 元禄 6 年(1693)に御目見御大工頭となり、延宝 7 年(1679)に御徒 並御大工頭となる。佐太神社貞享度造替では竹内有兵衛と共に「御 大工」 ${ }^{17}$ として携わるが、享保 3 年(1718)に留守居番組に入り士 格になっている。その倅作太夫 ${ }^{18}$ は享保 5 年に御徒並元 とあり、 元文 2 年に作事奉行 ${ }^{19}$ になってる。

上坂次郎左衛門は慶長 6 年(1601)、直政の父秀康の時代から 足軽並として仕元、越前大野で御大工となる。倅次郎左衛門は慶 安 2 年(1649)に御作事所に勤め始め、明暦元年に父の跡を継ぎ御 大工となる。その倅本兵衛は、貞享 2 年(1685)に御大工、元禄 14 年(1701)に御大工頭、宝永 8 年(1711)に御目見御大工頭に、享保 5 年(1720)に御徒並元 （梩兵衛に改名）となり、享保 9 年(1724) に目附に、享保 19 年(1734)に再び元み゙になっている。

馬場助右衛門は越前大野で足軽として仕え、出雲で御大工を 勤める。倅助右衛門は承応 2 年(1653)親と入代わる。その倅助右 衛門は寛文 8 年(1668)親と入代わる。以後しばらく記載がなく元 禄 6 年(1693)御大工（4 代目？）とある。また、しばらく記載が なく、享保 9 年(1724)に御大工 ( 5 代目 ?) とあり、享保 19 年(1734) には卸目見卸大工頭となっている。市之丞（後に助右衛門と改名、 6 代目?）は寛保 2 年(1742)に親と入代わり御大工、宝暦 10 年 (1760)に御大工頭助尔、明和 4 年(1767)に御大工頭となる。佐々 右衛門（7代目?）は安永 2 年(1773)に親の跡を継ぎ御大工、寛 政 8 年(1796)に御大工頭になり、寛政 11 年(1799)には、この『帳』 を記している。20

水谷五郎兵衛は越前大野では台所役人として仕え、出雲で御 大工になっている。倅五郎兵衛は万治元年(1658)に衔大工となる。 その倅五郎兵衛は貞享 4 年(1687)に御大工となる。その倅五郎兵 衛は元禄 17 年(1704)に親と交代して御大工に、正徳 3 年(1713) に御大工頭（勘右衛門と改名）となる。享保 19 年(1734)に徒目 附内改小普請方頭取とある（以後不明）。

竹内小右衛門は元和元年越前姉ヶ倚で桧皮方として召し抱え
られ、出雲で御大工となる。2 代目伊助は承応 2 年(1653)に父の 跡を継ざ、桧皮方を勤める。以後は『列士録』によると、寛文 12 年に御作事所役人となり宝永元年に逝去する（以下略す ${ }^{21}$ が、表3 では同系の竹内権三郎以下の系譜も載せている）。

森川甚兵衙は越前大野で足軽並として召し抱えられ寛氷 15 年(1638)に御大工となる。2 代目甚左衛門は、承応 2 年(1653)に 御大工になるが、宝承 5 年(1708)に「御大工隇し」とあり、家系 は跡絶える。

\section{2 ）御大工並の石抱}

『帳』をよく見ると、大工職の增員は主に御大工並の任用によ っているのが分かる。ここでは、御大工並の召抱について検証し、 松江藩における大工職の任用とその後の推移を明らかにしたい。

『帳』では、大工職が増員されたり、役職が変わる際に「見習」 「被召抱」「被仰付」等と記される。「見習」の記載は御大工(並) の倅に限られ、「無給」で始まり、後に親と代り御大工(並)とな るのが分かる。「被召抱」は御大工並に限って見られる。「御大 工並(二)被召抱」と記載されているのは、正德 3 年(1713) 4 人、享 保 3 年(1718) 7 人が顕著で、元文 3 年(1738) 1 人、延享 1 年(1744) 1 人、宝暦 13 年(1763) 1 人、明和 3 年(1766) 1 人、安永 8 年(1779) 1 人である。この他の記載例を見る。「御大工並」のみの記載が 享保 16 年(1731) 1 人、寛保 2 年(1742)6 人である。「御大工並增」 の記載は享保 7 年(1722) 1 人である。「御大工並被仰付」は元文 2 年(1737) 2 人、寛保 3 (1743) 年 1 人、安氷 4 年(1775) 1 人、明和 2 年(1765) 1 人、安永 3 年(1774) 1 人で、「御大工並勤被仰付」 が安永 3 年 1 人である。ところで、御大工並から御大工に変わる 場合には「被仰付」と記載されている。他の役職に変わる場合も 「被仰付」と記される。これは役人や奉行の場合も同じである。

大工や役人が他の役所から、あるいは他の役所に変わる場合も 「被仰付」と記される。一方「被召抱」は新たな㕍用に際して使 われているが、大工職の「被召抱」、つまり新たに㕍われる場合 に、御大工並から始まることが分かった。

表-4は「御大工並()被召抱」とある大工について、召抱の年 とその後の推移を示したものである。なお、寛保 2 年(1742)の「御 大工並」と記載される 6 人については表-4の下欄に附記したが、 彼等も前記「御大工並二被召抱」とその推移が相応しているとこ ろから、新たに任用された御大工並と見なすことができる。22

3 ）享保 3 年召抱の御大工並の推移 ${ }^{23}$

大工職の任用ついては前節でその特色を明らかにしたが、御大 工並の召抱が特に顕著なのは享保 3 年(1718)である。ここでは、 享保 3 年に御大工並に召抱られた 7 人を取り上げ、その系譜を辿 り、松江藩における大工職の推移に見られる特色の一面を検証し たい。

『帳』の享保 3 年の項の冒頭には「八重垣 伊丹堂 善光寺 御 修復／新橋 両三枚橋 掛直シ」と作事物件が記されているが、 この頃、御作事所の員数 ${ }^{24}$ も多くなり、 7 人の御大工並を新たに 召抱ることになったと考えられる。これら 7 人の系譜を辿ってみ ると、表- $5{ }^{25}$ のようになる。以下に個々の推移を辿ってみる。

井川源四郎は享保 21 年(1736)に御大工、寛保 3 年(1743)に御 目見御大工頭になり、寛延 4 年(1745)に倅と入代わる。倅新之丞 は親源四郎が御大工になる寛保 3 年に御大工見習として御作事所 


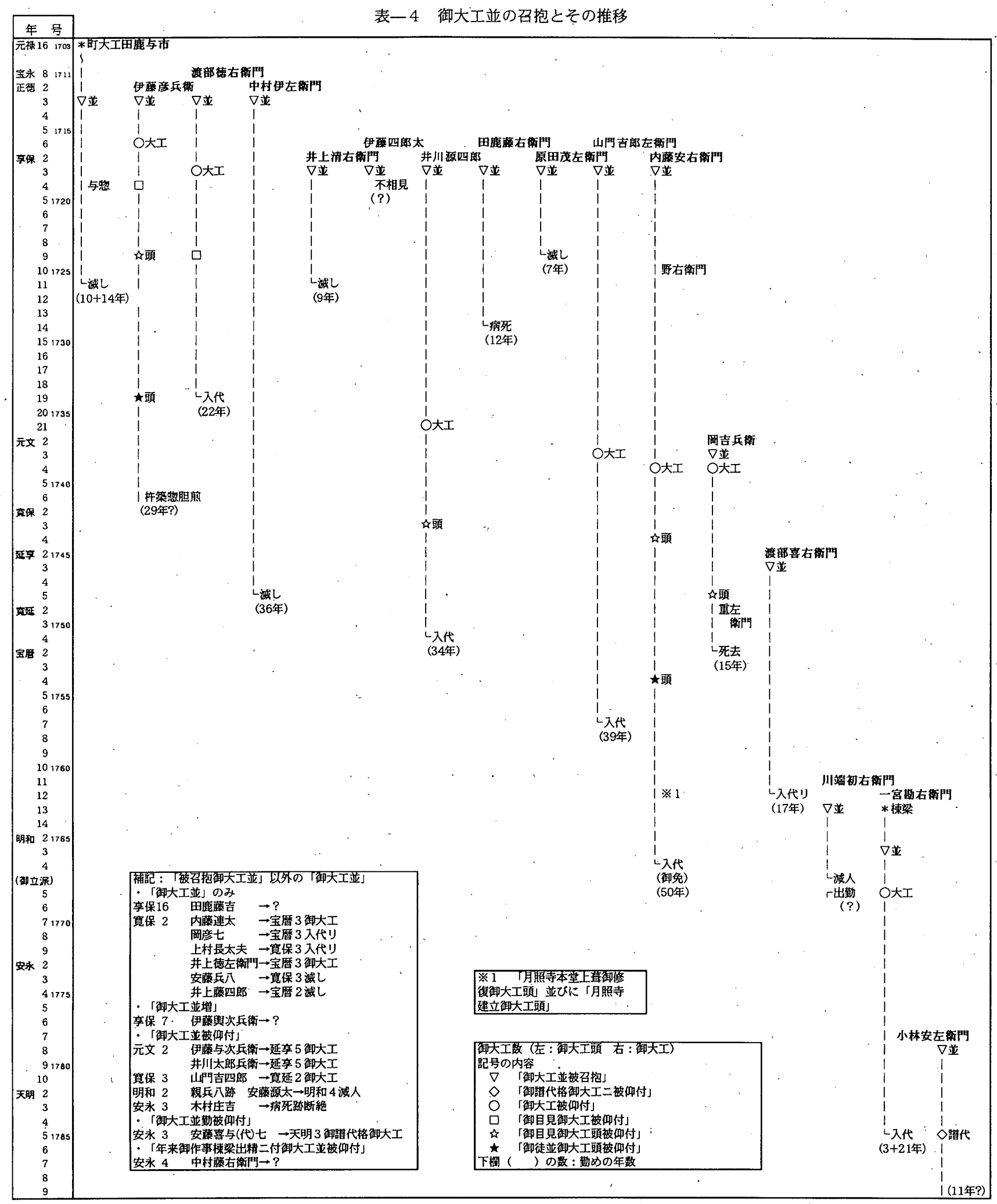

に勤めはじめ、寛延 3 年(1750)に親に代わうて御大工になり、同 時に名を源四郎と改め、宝暦 6 年(1756)病死とある。その倅次郎 吉は同 7 年(1757)に御大工に、同 9 年(1759)に源四郎と改め、明 和 4 年に官七と改名し御大工普請所勤となり、安永 6 年(1777)に 江戸勤（この時、伊祖助と改名）、安永 9 年(1780)に江戸より帰 り、天明 5 年(1785)に御破損方支配御大工頭になる。天明 6 年以 降の『帳』にはしばらく名が見えないが、寛政. 2 年以降、徒並御
破損方御大工頭として名が再び見えている。なお井川姓には他に 太郎右衛門、嘉兵衛、善右衛門等の名が見える。

田鹿藤右衛門は享保 14 年(1729)に病死とある。翌 15 年(1730) に御大工並藤右衛門跡として田鹿藤吉の名が見えるが、同 16 年 （1731）には「隇し」とあり、以後、田鹿性は見えない。

伊藤四郎太はこの年に朱で「相不見」とあり以後の動向は判 らない。同姓の伊藤与次兵衛が元文 2 年(1737)に御大工並となり 
表-5 享保 3 年召抱御大工並の系譜

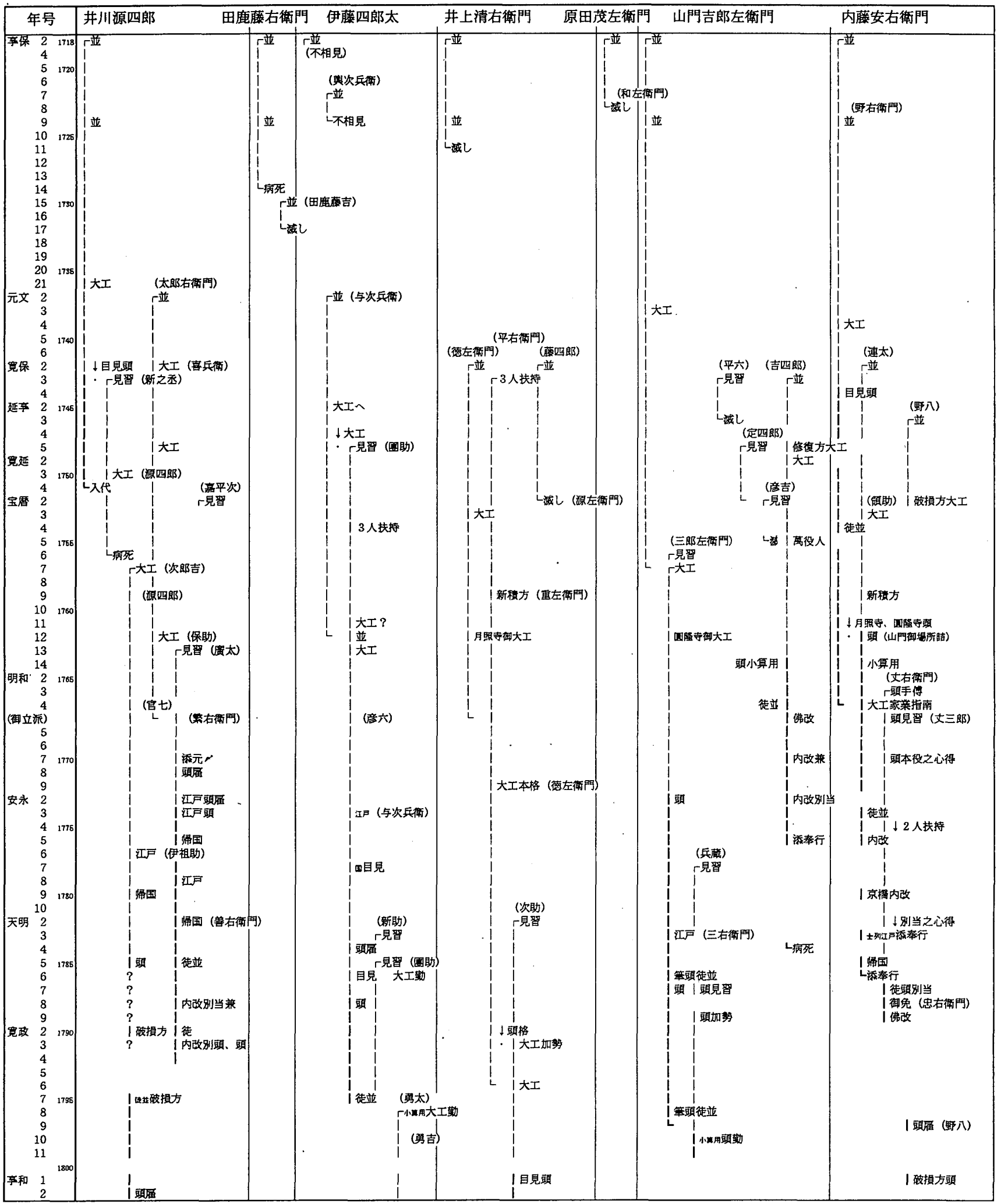

以後家系は 3 代に渡って継続しているが、伊藤團助は延享 5 年 （1748）に御大工見習となり、宝暦 12 年(1762)には親に代わって 御大工並に、翌 13 年(1763)には御大工となり、さらに、天明 4 年(1784)には御大工頭雇に、同 8 年(1788)には御大工頭になり、 寬政 7 年(1795)には御徒並になってる。

井上清右衛門は享保 11 年(1726)に「滅し」とある。その後
は同姓の井上徳左衛門が寛保 2 年(1742)に御大工並になり、宝暦 3 年(1753)に御大工に、宝暦 12 年(1762)の月照寺 ${ }^{26}$ 本堂上莫御修 理では 4 人の御大工の一人で、明和 4 年(1767)に倅重左衛門と入 代わりとなる。徳左衛門の倅平右衛門は寛保 3 年(1743)に三人扶 持で見習（?）となり、宝暦 11 年(1761)にはすでに御大工にな り、月照寺修理でも御大工として名を連ね、明和 4 年に親と入代 
わり（この年、重左衛門と改名）、明和 5 年に三丸瓦屋根方勤と なり：明和 9 年(1772)に御大工本格（この年、徳左衛門と改名） を仰せ付けられ、寛政 3 年(1791)に御大工頭格となっている。

原田茂左衛門は啍保 8 年(1723)に「隇し」とあり、以後、田 原姓は見えない。

山門吉郎左衛門は元文 3 年(1738)に衔大工、宝暦 7 年(1757) に隠居し、倅三郎左衛門と入代わる。倅三郎左衛門は宝暦 6 年 （1756)に見習となり、同 7 年に入代わり御大工となり、同 12 年 の圓隆寺 ${ }^{27}$ 本堂建立でも御大工として名を連ねている。明和 4 年 には御大工御普請所勤、寺院方普請所勤兼とあるが、安氷 2 年 (1773)には小作事添元よ゙御大工頭兼となり、同 5 年(1776)に小作 事添元メ御免、天明 3 年(1783)に江戸勤番（三右衛門と改名）、 同 6 年(1786)に帰国し御大工頭となり、御徒並になっている。寛 政 5 年(1793)に吉郎左衛門と改名、寛政 9 年(1797)に病死する。 その卒兵蔵は安永 7 年(1778)に御大工見習となり、天明 7 年には 御大工頭加勢に、寛政 3 年(1791)に御大工頭加勢・御普請所勤、 寛政 9 年に跡を継ぎ御小算用大工頭勤となっている（享和元年以 降は不明）。

内藤安右衛門は元文 4 年(1739)に䘖大工となり、寛保 4 年 (1744)に御目見御大工頭に、宝暦 4 年(1754)の御徒並御大工頭に、 明和 4 年(1767)に御免となっている。倅連太は寛保 2 年(1742)に 御大工並となり、宝暦 3 年(1753)に御大工に（この年、領助と改 名)、宝暦 12 年(1762)の月照寺本堂上惪御修理と圓隆寺本堂建 立では御大工頭となり、同 14 年(1764)に小算用に、明和 4 年に 御大工家業指南となり、安永 3 年(1774)に御徒並、同 5 年(1776) 内改、天明 3 年(1783)には土列御取立添奉行となってる。その倅 丈右衛門は明和 3 年(1766)御大工頭手傅に、明和 7 年(1770)には 御大工頭本役之心得となっている。

\section{5. 御大工の位固付けとその推移}

御作事所には、まず組織を統率する作事奉行とそれを補佐する 添奉行が置かれ、その配下には、事務（計吏）系として調役、内 改、横目、元 、役人等が置かれ、技術系として御大工頭、御大 工、御大工並（譜代格御大工）、御左官等が置かれ、それらを助 ける役職として城普請、小夫等が置かれたが、それらの陣容は天 明 6 年当時およそ 70 名であった。

御作事所における御大工の位置付けと任務について述べる。 役職と格式は不可分に対応している。大工職は徒以下の卒分で、 奉行、添奉行になって士分になる。御大工を中心にその推移を見 ると、御大工から御大工頭、添奉行、中には本奉行へと昇格する 者がある。

御大工は御作事所の普請所勤めが主体であるが、破損方、寺社 修理方等も併置されている。

江戸での勤めも重要な任務で、添奉行、大工頭、御大工等は交 互に「江戸勤番」になっている。

これらのことから、御大工は優れた技倆を持ち、統率力のある 者が求められていた。また、御作事所は御大工を重用した組織で あり、御大工を中心とした職能集団であったことが分かる。

御大工の任用とその推移については次のような特色が見られた。 徳川家康の庶長子結城秀康の第三子・松平直政は、寛氷元年か
ら 10 年間越前大野を領し、寛永 10 . 年から松本、寞永 15 年から 出雲国を領するが、寛永 15 年召抱御大工 7 人はいずれも越前が 生国であり、大野時代に直政に（上坂氏は秀康の代から）仕えた 足軽であった。前藩主に仕えていた家臣にも作事に長けた武士（例 えば寛文の杵築造営の大奉行になった岡田半右衛門等）がいた筈 だが、直政は、松江入府の際、御作事所設営に当ってはそれまで 仕えた家来（足軽）で固め、城郭や城内の殿館等の修覆造営整備 に当たらせようとしたことが分かった。

正徳以降、御大工の任用は御大工並を召抱ることによって行わ れることになる。御大工並の石抱とその推移は多様である。町大 工や棟梁から御大工(並)になる例がいくつか見える。田鹿与市は

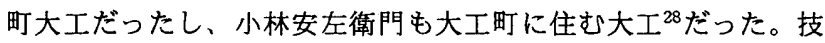
倆が備わっておれば町大卫や大工棟梁からの御大工(並)への登用 もあり、また、カと働きのある大工は御大工並から御大工、そし て御大工頭となり、それに相応して格式も高くなっていった。御 大工並の召抱とその推移を見ると、松江藩では、大工職の任用や 登用が、大工の技倆や働きに応じて行われる場合が多々あったこ とが伺える。

享保 3 年に召抱られた御大工並 7 人の系譜を迕ってみると、田 原茂左衛門のように短命な者、内藤安右衛門（後、野右衛門と改 名）のように卒が受け継いで添奉行にまで昇進する家系まで、そ の推移は個々の大工職によって異なっていることが分かった。

なお、松江藩においては子々孫々まで伝わる大工職の系譜は馬 場助右衛門の家系以外には確認できなかったが、それでも、『帳』 を辿ることによって竹内有兵衛を初めとしてして特筆すべき御大 工の存在が確認できた。

\section{6. おわりに}

本研究は、江戸時代における地方の作事組織の実態と組織形態 の特色を考察することを目的としている。本稿では、『帳』によ り藩政時代の主要な期間（寛永 15 年〜享和 2 年）における作事 粗織の実態を御大工の系譜を中心に検証してきた。御大工の系誁 を辿ることによって御作事所における御大工の位置付けと推移を 明らかにすることができた。

また、松江藩御大工の中には特筆すべき御大工の系譜が何人か 見られる。竹内有兵衛、上田六太夫、上坂次郎左衛門、水谷五郎 兵衛、竹内久右衛門、山門吉四郎、斎田彦四郎、安藤喜代七等の 系譜については『列士録』も存在するところからいずれも卒分か ら士分になった家系であることが明らかになった。

なお、『帳』に加えて『列士録』等の史料をよく見ると、例え ば、斎田彦四郎については、御天守の模型を作ったり、城内分限

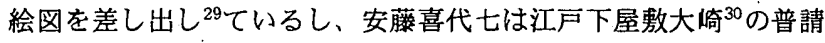
に関わったりしたことが推察できる。、今後は、特筆すべき御大工 の活動とその系譜をさらに詳しく検証すること、さらには、これ ら御大工の活動内容を詳しく調べ; 御大工が関与した作事等につ いても検討を加えることを課題と考えている。

\section{㭪郡}

本研究の基礎史料である『艮』であるが、所有者である野津隆 氏には、史料の閲覧並びに複写で御協力いただいた。また、『下 
按』、『列士録』等の調査では島根県立図書館郷土資料室にお世 話になった。ここに記して謝辞としたい。

なお、本稿は平成 $9 \sim 12$ 年度の科学研究費助成による研究成果 の一部としてまとめたものである。

\section{注記}

1 『御作事所御役人帳』は昭和 16 年に刊行された『松江市誌』の編集作業 中に収集され、現在は編者野津清一郎の遺族野津隆氏によって保存されて いる.

2 拙稿 : 松江藩御作事所の構成とその推移一松江藩御作事所と御大工の作 事に関する研究 その 1-, 日本建築学会計画系論文集 No.504,211217,Feb.,1998.

${ }^{3}$ 本章は拙稿: 松江藩御作事所の人員構成ニツイテー松江藩御大工の研究 その 3 一, 日本建築学会中国支部研究報告書 第 22 号, 1999-3.

4 国文学研究資料館史料館蔵「雲州松平家文書」の内の一つ，島根県立図

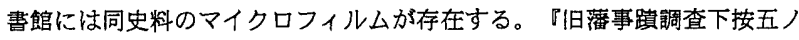
拾壹』では「(1)宗門奉行、(2)勘定奉行勝手方、(3)京都及大坂御留守居、(4) 隠州郡代、(5)郡奉行、(6)人参方・不実方奉行、(7)御船奉行、8御納戸役、 (9)御花烟奉行、(10御普請奉行、(1)御作事奉行、(1)御臺所奉行、(13)御札座奉 行、(4御軍用方添奉行!之14項目について記されている.

${ }^{5}$ 本章は拙稿 : 天明 6 年松江藩御作事所の構成之御大工の動向一松江藩御 大工の研究 その 4-, 日本建築学会大会学術梗概集(中国)1999,9. 55-56. に加筆修正を施したものである.

${ }^{6}$ 天明 6 年の『帳』に小夫の数は記されていないが、前後の『帳』を参照 に6名とした

7 御作事所の買数は藩政改革『御立派』によって御作事所の員数は 38 名ま て減少するが、以後、暂時増加する，前稿に記した「御作事所の陣容とそ の推移」でその変化を記している.

この表は中原健次著『松汇藩格式と職制』（松江今井書店, 平成 9 年) 等を参考に作成したものである.

8 岛㮛県立図㫪館藏 : 同様の史料として『列士録』以外には、『列士録新 番組拔取帳』、『列士録断緦帳』がある.

${ }^{10}$ 本章は拙稿 : 寞永 15 年召抱御大工と之の子棌の系譜一松江藩御大工の 研究 その 1 --日本建築学会大会講演梗概集(近畿),1996-9 に加筆修正を 施したものである。

11 史料により宇兵衛、右兵衛との記載もあるが、ここでは有兵衛に統一す る。但し『竹内右兵衛書付』についてはそのまま表記した.

12 『列士録』には「於江戸御出入御奉公」とある.

13 『藩主事蹎』には「公江戸西の御丸御普請御手傅の命を蒙られ、（慶安 二年）九月二十六日手䆑始めあり、時に岡田信世御普請の大奉行たり」と ある.

14 『佐太神社貞亨四年指図板』（島根県立博物館藏）に記さている.

15 『竹内右兵衛書付』は縦 $7.5 \mathrm{~cm}$ 、横 $15.6 \mathrm{~cm}$ 、緍数 114 枚からなる和経 本である。内容は(1)略年表 4 枚、(2)家相之部 4 枚、(3)武家之部 65 枚、(4) 松江城遊実測之部 24 枚、(5)奥書 1 林に分かれており、特に松江城邡に関 する記述は重要で松江市保讙文化財に指定されている.

16 『帳』には 3 代目までしか記載されていないが、『列士録』によると、 以下の通りである. 4 代目伴兵衛は正徳 2 年(1712)に御作事所見習となり、 享保 7 年(1722)に父の跡を継ざ御徒並となり、元メ、横目役を勤める。 5 代目伴兵衛は元文元年(1736)に小算用となり梅作事所から離れる．以下は 『列士録』によるが、6 代目武太夫は安永 5 年(1776)に御徒並となり、文 化 6 年(1809)の出雲大社修覆、その後「若殿様御殷普請」にも捲わり、文 政 12 年(1829)には土格になっている.

${ }^{27}$ 佐太神社賁享四年建立棟札には「御大工 上田六太夫竹内宇兵衛」と 並記されている.

is『列士録』によると、3 代目作太夫は享保 10 年(1725)に父の跡を継ざ留 守居番組に組入し、元文 2 年(1737)には作事奉行となる（延享 3 年まで），
この間松江大橋の普請、出雲大社の延享度造替で出精し露美を賜る。4 代 目作太夫は父の跡を継ざ士格として大番組に組入する。 5 代目友之助は新 藩士（卒）に戻っている。その後は不明.

19 『列士録』には元文 2 年に「御作事奉行被仰付役組外（後略）」とあり 延亨 2 年に! (前略) 御作事奉行後上御兔 勤之年数十ケ年 大番組江組 入」とある。

20 『悢』は筧永 15 年から享和 2 年までの作事所の変動を記した史料であ るが、最初から最後まで名が見えるのは馬場姓だけである．このことから 馬場氏は生きの長い御大工の家系であったことが分かる。

『帳』の「筧政十一未年」の末尾に「右之通御座候以上未正月 馬場佐々 右衛門 江角新藏」とあるが、当年、馬場佐々右衛門は御大工頭筆頭、江 角新蔵は御役人筆頭である.

21 『帳』には元禄 8 年に御役人竹内伊助の名が確認でき。『帳』には元禄 8 年(1695)加御作事所御役人、元禄 6 年(1695)に御目見となる. 3 代目 伊助は元禄 2 年御作事所見習に、同 11 年に父の跡を秤ざ御役人となる。 4 代目小太夫は正徳 3 年に御料理方見習となり、以来台所方に勤め、延亨 2 年に士格となり、宝暦 12 年から御台所奉行を勤める（安永 4 年まで）。

22 「御大工並」の呼称であるが、『帳』では天明 3 年以降は「謭代格御大 工」と名称が変わっている.

${ }^{23}$ これは拙稿 : 亭保 3 年召抱の御大工並の推移一松江藩御大工の研究 そ の 6一, 日本建築学会大会学術梗概集(東北)2000,9．55-56.に加筆修正を施 したものである.

${ }^{24}$ 享保 3 年の貝数は 100 人で前年より 30 人增加している. その内小人か 11 人から 31 人に、御大工が 11 人から 15 人になっているのが顕著である。

${ }^{25}$ 一部に空白部分があるが『帳』に記載されていないためである.

${ }^{26}$ 松江落主の菩堤寺で初代直政はじ藩主の需朝がある。

${ }^{27}$ 歴代将軍の需位が安置されている寺院て、松江藩で清水寺や艁㴊寺と 同格に扱われていた。

${ }^{28}$ 『松江八百八町 町内物語 $=$ 白鼬の町 $=8$ (同患編纂協会編, $\mathrm{S} 30$ 年 3 月） に記されている.また、小林安左衛門は松江藩の名工小林如泥の親である。 29 『列士録』には「同（亭保三）年月日不知天守小形疗（後略）」「同（亨 保）五庚子年三月日不知御城内分限御給圖被仰附出来差出（後略）」と ある.

${ }^{30}$ 大崎下屋敖は松平不昧が営んだ独楽庵を始めとする茶室建筑や数寄屋建 築でも著名であった。

‘(2000年 8 月 29 日原稿受理, 2001 年 1 月 15 日採用決定 $)$ 